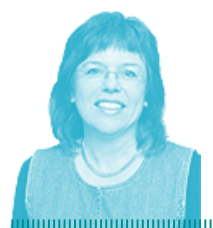

Synne Heivang, kursrådgiver, Senter for sjeldne diagnoser, Oslo universitetssykehus HF, Rikshospitalet

\section{FAG Sjeldne diagnoser}

Jeanette Ullmann Miller, rådgiver/fysioterapeut, Senter for sjeldne diagnoser, Oslo universitetssykehus HF, Rikshospitalet
Gunvor A. Ruud,

rådgiver/bioingeniør,

Senter for sjeldne diagnoser, Oslo universitetssykehus HF, Rikshospitalet

\title{
Huntington på nett
}

\author{
Nettbaserte kurs gir helsearbeiderne økt kunnskap og pasientene bedre livskvalitet.
}

0 enter for sjeldne diagnoser har over tid sett et økende behov for kunnskap om Huntingtons sykdom (HS). For å møte dette behovet har vi utviklet et nettbasert kurs for fagpersoner. Målet med kurset er å gi økt kompetanse og trygghet for fagpersoner i møtet med sjeldne diagnoser. Senter for sjeldne diagnoser har flere års erfaring fra møter, kurs og telefonsamtaler med personer som har Huntingtons sykdom, deres pårørende og fagpersoner. Vårt inntrykk er at det finnes mye kompetanse og drives god behandling i hjelpeapparatet, men at usikkerheten blir stor når diagnosen er sjelden og ofte helt ukjent for fagpersonene.

\begin{abstract}
Målgruppen
I løpet av fire år har cirka 300 personer, hovedsakelig sykepleiere og hjelpepleiere, men også andre fagpersoner deltatt i opplæringen. Forutsetningen for å delta er at man møter personer med Huntingtons sykdom i arbeidet sitt. Vi ser at deltakerne, i et lukket forum, deler erfaringer og diskuterer problemstillinger de er opptatt av. Mange opplever dette som nyttig, en kursdeltaker sier: «Diskusjonsforum har vært
\end{abstract}

\section{Hovedbudskap}

Vi ønsker med denne artikkelen å vise hvordan vi har tatt i bruk nye medier i opplæring og veiledning. For fagpersoner som arbeider med sjeldne diagnoser kan det lave pasientgrunnlaget begrense muligheten for kompetanseutvikling. Nettbasert kurs er en interaktiv, variert, fleksibel og økonomisk måte å lære på, og har vist seg velegnet som opplæring og erfaringsdeling for faggruppen.

\section{Nøkkelord}

Les mer og finn litteraturhenvisninger på våre nettsider. Nevrologi \Kurs IInternett svært nyttig, da det er lærerikt å lese andres refleksjoner rundt de ulike temaene. Meget relevant kursinnhold, som er svært aktuelt i min jobb med personer med HS.»

\section{Hvorfor e-læring?}

Da vi begynte å planlegge et nettbasert kurs om Huntingtons sykdom, hadde vi i noen år arrangert ordinære kurs på ulike steder i landet. Vi så at det var behov for å effektivisere opplæringen, både for oss som kursholdere og for fagpersonene som ville delta. Ved å legge undervisningen på nett mente vi å kunne nå fagpersoner fra hele Norge samtidig. Fleksibilitet var også en viktig faktor for deltakerne. Flere fra samme arbeidsplass kan delta på kurset samtidig fordi det ikke krever lengre fravær fra jobb, og på grunn av lave kurskostnader.

\section{Evaluering}

Evalueringene viser at deltakerne er positive til denne måten å lære på, og at de har hatt faglig utbytte av kurset. De fleste setter pris på fleksibiliteten et e-læringskurs gir i forhold til tradisjonelle kurs. En av forskjellene på elæringskurs og tradisjonelle kurs er at både fagstoffet og andre deltakeres innspill og innlegg er tilgjengelig for å kunne leses flere ganger. Dette har flere påpekt som nyttig: «E-læring er et godt alternativ til tradisjonelle undervisningsmetoder fordi det er fleksibelt. Jeg kan studere når det passer meg.»

Mot slutten av fjorårets kurs ba vi deltakerne reflektere over sin egen praksis. Det var god oppslutning om refleksjonsnotatene, og det kom fram at flere av deltakerne har fått ny innsikt $i$ sykdommen. De gir eksempler på hvordan de har endret sin praksis og dermed fătt et bedre samspill med pasienten. En av kursdeltakerne uttaler: «Jeg synes selv jeg har endret måten jeg jobber på ... mest på hvordan man kommuniserer med pasienten. Nå kommuniserer vi ikke mens hun spiser, sitter rett ovenfor under måltid, og det viktigste av alt - nå tilbyr vi ikke henne valg fra hele kjøleskapet når hun skal ha lunsj! Føler selv at jobben jeg gjør med pasientene har mer faglig tyngde, og jeg føler meg mer selvsikker i de valgene jeg tar.»

\section{Kurset}

Vi arrangerte e-læringskurset første gang i 2009. Målgruppen er ansatte i sykehjem, omsorgsboliger og hjemmetjenesten. Hensikten er å øke livskvaliteten for pasienter med Huntingtons sykdom gjennom å styrke kunnskap om diagnosen hos pleie- og omsorgspersonell. Deltakerne logger seg på kurset med brukernavn og passord. De kan lese fagstoff, se film, skrive diskusjonsinnlegg og gjøre oppgaver når det passer dem. Fordi menings- og erfaringsutveksling er en viktig del av kurset, er det felles oppstart i januar hvert år. Fagstoffet er delt inn i seks moduler, som blir tilgjengelige etter hvert i løpet av kursperioden, som varer i tre måneder:

, Diagnoserettet kunnskap

, Kommunikasjon med pasienten

, Ernæring

, Dagliglivet

, Familien og barna til den syke

, Utfordringer ved endret atferd

E-læringskurs er interaktive på en annen måte - og for mange deltakere i større grad, enn klasseromskurs. I denne opplæringen har vi dessuten lagt stor vekt på at deltakerne skal reflektere over ulike temaer, både i diskusjonsforum og i innleveringsoppgaver. Årsaken er at $i$ arbeidet med pasienter med Huntingtons sykdom kan man komme opp i mange situasjoner som det ikke finnes fasitløsninger på. Grundige etiske refleksjoner, også sammen med kollegaer, er derfor en viktig del av arbeidet. Opplæringen er godkjent av Norsk Sykepleierforbund og andre forbund som 20 timers etterutdanning. 
KOMMUNISERER BEDRE

Mange helsearbeidere opplever

å ha endret kommunikasjonen

med pasienter med Huntingtons

sykdom etter å ha deltatt på kur-

set. Illustrasjonsfoto: Colourbox

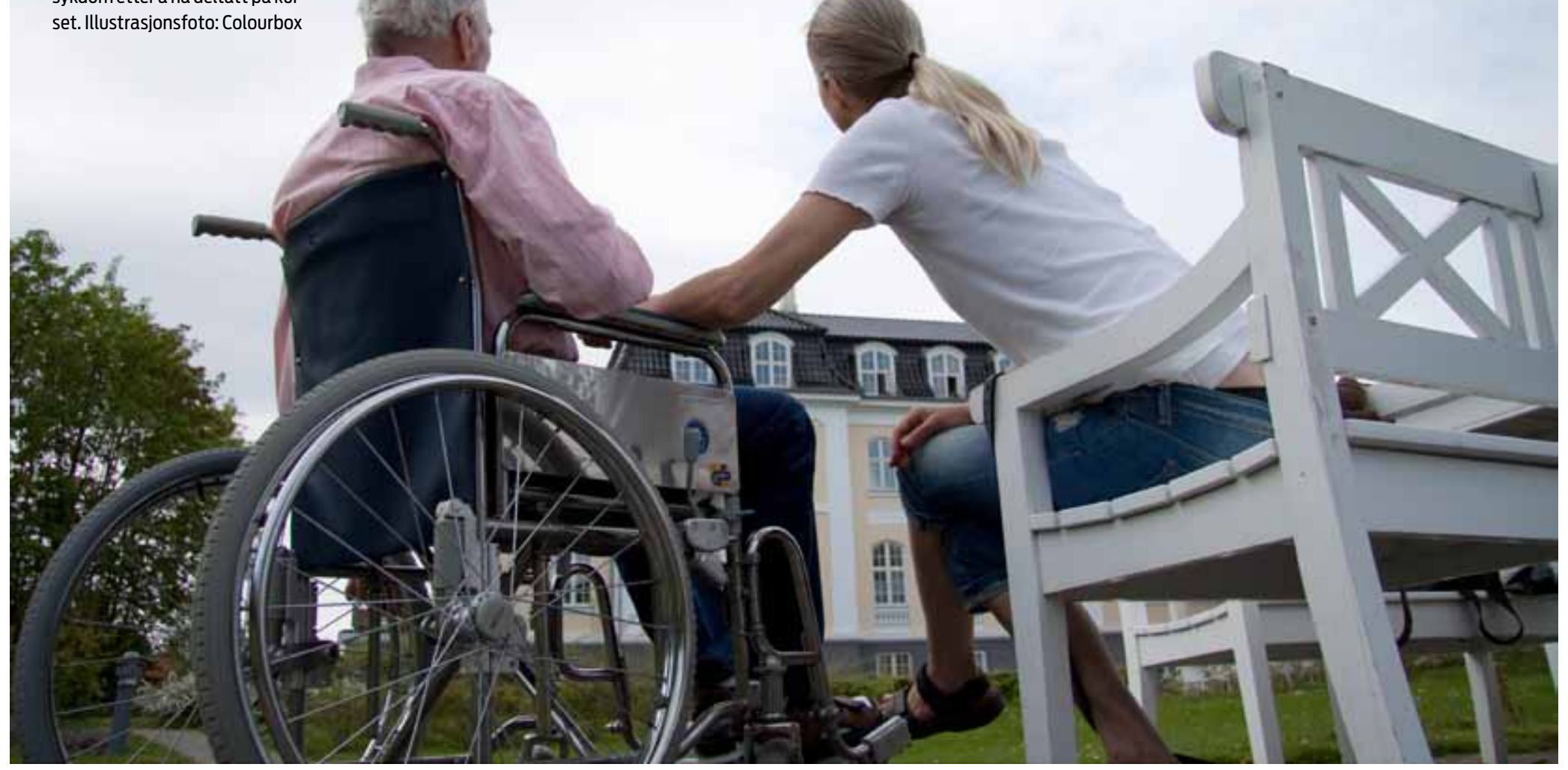

\section{Videreutvikling}

Hvert år justerer vi fagstoffet til ny kunnskap og erfaring, deltakernes evalueringer og nytt lovverk. Modul 5 om barn og familien ble lagt til i 2011. En kursdeltaker kommenterer dette slik: «Jeg har fått et større fokus på barna til pasientene med HS, spesielt de med små barn. Jeg har nå mer kjennskap til hvilke utfordringer disse barna har, og jeg har fått økt kunnskap om hvilke forpliktelser jeg som helsearbeider har overfor barn som pårørende. På bakgrunn av dette har jeg begynt å legge det inn som et fast punkt i ankomstsamtalen med pasient og pårørende.»

\section{Engasjement}

Deltakerne har vist stort engasjement. De har deltatt i diskusjonsforum og levert besvarelser. I snitt har 63 prosent av deltakerne fullført hele kurset og fått kursbevis, og 75 prosent har gjort mesteparten av kurset. Dette er vi godt fornøyde med. Vi erfarer at dette samsvarer med deltakelsesprosenten på vanlige kurs.

\section{Diskusjonsforum}

Diskusjonsforumet legges opp som erfarings- og meningsutveksling mellom kursdeltakerne. De emnene vi legger ut blir ofte oppfattet som oppgaver og får mange like svar - særlig på store kurs med 80-90 deltakere. Noen av deltakerne forventer at vi skal kommentere innleggene, hvilket vi bare har gjort dersom vi har blitt spurt om noe eller hvis det har kommet fram uriktig informasjon. Hvis vi ser at det er lite aktivitet i forumet, vil vi stille spørsmål for å øke engasjementet. Når deltakerne presenterer reelle problemstillinger, ser vi at de får gode innspill og råd fra hverandre. Utfordringen med disse diskusjonene kan være å ivareta taushetsplikten. For å unngå å identifisere pasienter oppfordres deltakerne til å anonymisere sine innlegg og ikke fortelle hvor de jobber.

\section{Ny kunnskap}

På mange arbeidsplasser har flere kolleger valgt å delta samtidig. De forteller at dette har vært nyttig og ført til gode faglige diskusjoner og felles rutiner. Dette er en viktig tilbakemelding, da forutsigbarhet er av stor betydning for denne pasientgruppen og gir personalet større trygghet.

Det er hvert år tre-fire rådgivere som har ansvar for kurset. Det er en del arbeid å kommentere besvarelser og følge diskusjonsforumet, men dette er arbeid som kan gjøres i ledige stunder. Rådgiverne forteller at svar og innlegg fra deltakerne gir dem verdifull innsikt i hverdagen til helsepersonell som arbeider med pasienter med Huntingtons sykdom. Mange av innleggene utfordrer rådgiverne til å søke ny kunnskap om sykdommen.

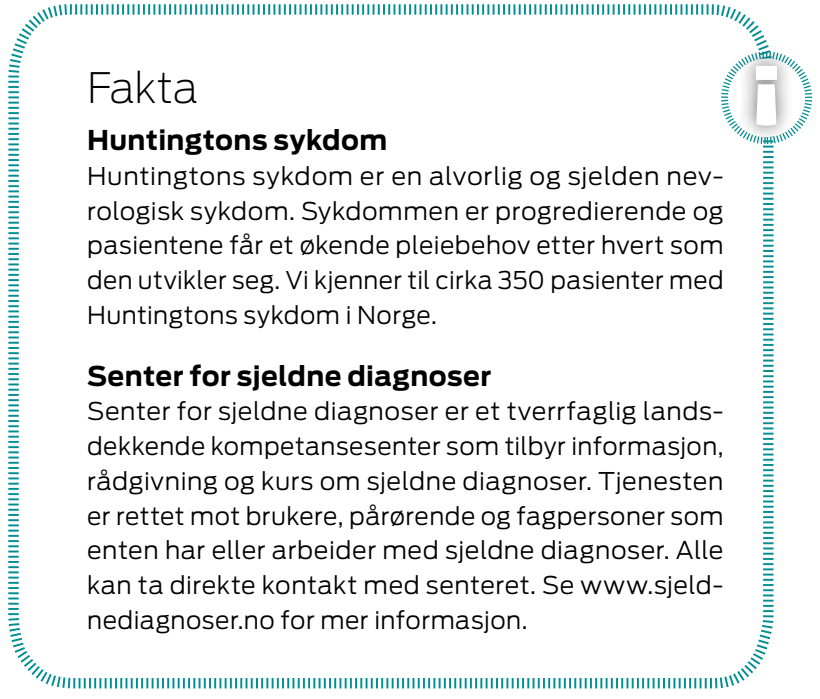

\section{Konklusjon}

Basert på evalueringer og tilbakemeldinger om kursets nytteverdi, har vi vedtatt at kurset skal arrangeres årlig og utvikles kontinuerlig med tanke på brukererfaring, ny kompetanse og forskningsresultater. III

Fagartikler kan sendes til torhild.apall@sykepleien.no 